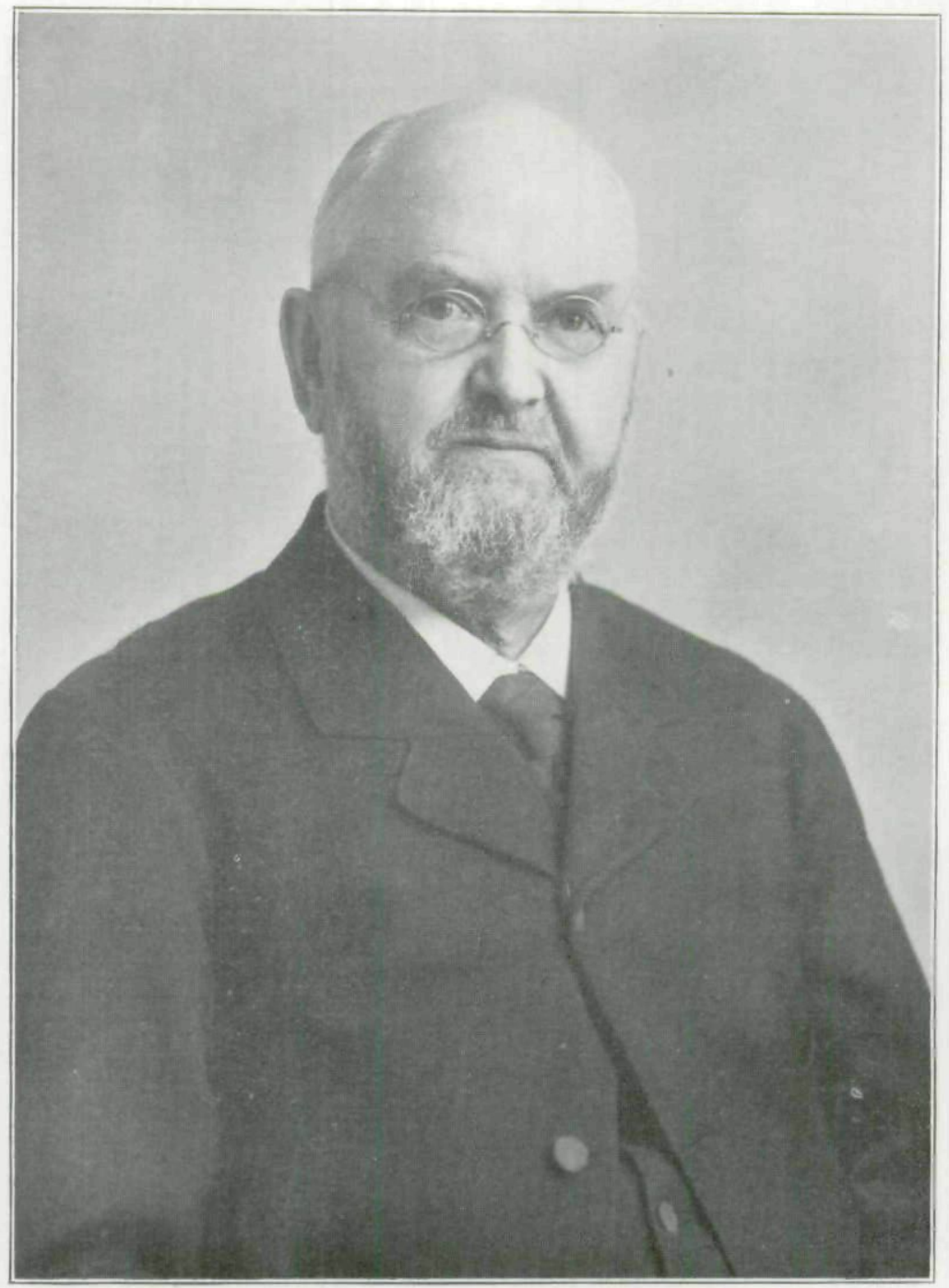

Belive one my deas Max. Hediech. alvaye fritty ntly yours.

Pharles of. Thite: 


\section{LIFE AND WORK OF CHARLES ABIATHAR WHITE.} By Charles Keyes.

There was recently claimed by Death another of the great scientists of our country - an Iowan withal. Iowa is unfortunately prodigal with her brains. Singular as it may seem she appears to be the one State in all the Union which is constantly producing the largest number of exceptional minds in proportion to her population while she retains the fewest. Dr. Charles Abiathar White was no exception to this rule. For seventy-two years he was a resident of Iowa; one-half of this long period dwelling in Washington, but still retaining his home in this State and actively interested in its affairs. During a round half century he was a copious writer on many themes and his important contributions to geologic science were above two hundred in number.

The subject of our sketch was born at Dighton, Bristol county, Massachusetts, January 26, 1826 ; and died in Washington, D. C., June 29, 1910. His residence in Iowa dates from his twelfth year of age, when he eame with his parents to Burlington when our commonwealth was yet a territory.

Charles White was the second son of Abiathar and Nancy White, the latter a daughter of Daniel Corey. His forbears were among the earliest settlers of New England, having come over to this country from Old England within twenty years after the Pilgrim fathers landed on Plymouth Rock. The White homestead in Dighton was held by the successive members of the family for a period of more than two hundred years.

In New England White's ancestors were tillers of the soil; but they were also always active in the business and public affairs of their neighborhood. So strongly were they attached to their native heath that it is said that no member of the family for a period of more than one hundred and fifty years ever travelled a greater distance from home than fifty miles. 
When, finally, the Wanderlust which, in the middle of the last century became so prevalent throughout the older parts of the country, penetrated to Charles' family, the latter moved to the Mississippi river and took up residence in the vicinity of Burlington, Iowa. At this momentous time in Charles' life he was twelve years old. The Black Hawk war had recently elosed and the Indian lands west of the Mississippi river had been thrown open to settlement. The country was then the newest. In a typically pioneer home young White grew up to manhood amid many privations and seeming disadvantages. For a number of years he worked as a mechanic, but his interest early turned to the rocks and their curious remains of ancient life. Large collections of fossils were acquired and studied. The little farm on Flint river (four miles north of the town) happened to be near what afterwards proved to be one of the most famous and prolific localities for organic remains in the world.

In 1847 , when he was twenty-one years of age, young White paid a visit to the old New England homestead at Dighton. It was there during the following year that he was married to a childhood school-mate, Charlotte Pilkington. With his young wife he returned to Burlington, where he continued to live for a decade and a half. For fifty-four years they were spared to each other. Eight children were the fruit of this happy union.

During the fifteen years of his residence in Burlington were laid the foundations of White's scientific career. The labors which had brought him his daily bread became gradually more and more irksome. Through local studies of the rocks and the flowers he was led to more systematic effort. The love for natural history matters thus acquired never left him while life lasted. From the Burlington rocks he made large collections of the fossils. These collections were especially rich in beautiful crinoids, or "stone lilies," for which the locality became so famous the world over. His first scientific paper, published by the Boston Society of Natural History, is a reeord of some species new to science, found in the vicinity of Burlington. 
White's interest in ancient organic remains contained in the rocks of Burlington grew rapidly. With Charles Wachsmuth, Otto Thieme and Amos Worthen, who lived a few miles down the river at Warsaw, he collected fossils and recorded facts. Visits to Burlington by Louis Agassiz, James Hall, Doctor Perry and F. B. Meek, greatly enlivened the enthusiasm of the little local coterie of embryo scientists. The discoveries by the Iowa men of hundreds of fossil forms entirely new to science soon made these modest workers widely known.

At this time White made numerous trips into various parts of the Mississippi valley and his knowledge and breadth of mind grew apace. The discoveries made on these journeys led him to accept an assistantship with Professor Hall, of Albany, New York, one of the foremost of American geologists. There the years 1862 and 1863 were happily and very profitably spent. Separately and in conjunction with several other workers on the Hall staff, he published the results of his first scientific investigations.

With a large family to support, White had to look closely into the means of getting a livelihood. In those days dependence upon purely scientific work was a precarious course. His inclinations were turned towards the practice of medicine. A few years previous to going to Albany he had taken up the study, in the office of Dr. S. S. Ransome, one of the leading physicians of that day in the new State. He then attended the medical school at Michigan State University, selling to that institution his collections of fossils in order to defray his expenses. Finally, in 1864, at the age of thirty-eight, he was graduated with the degree of M. D., from Rush Medieal college of Chicago. The same year he removed with his family from Burlington to Iowa City, and began the practice of medicine, following this vocation for two years, when by legislative enactment he was made State Geologist.

In taking up the duties of state geologist Doctor White entered in earnest upon his career as a scientist and an author. For a period of more than forty years thereafter his pen was seldom idle for any great length of time. As State Geologist of Iowa he served four years; and two large volumes attest 
his energy and industry and that of his two chief assistants during that period.

In 1867 Doctor White was appointed to the chair of natural history in the Iowa State University. During the next three years he only devoted a part of his time to school duties. The department was then new and students were few in number. In succeeding years he gave all his time to the University, until, in 1873, he accepted a eall to Bowdoin College at Brunswick, Maine. There as Professor of Natural History, he remained two years, and then took up his abode in Washington, D. C.

From this time onward Doctor White was never again closely in touch with educational affairs. But colleges had come to recognize his work and worth. In appreciation of his achievements honorary degrees conferred upon him include that of Master of Arts, by Grinnell College in 1866; and that of Doctor of Laws, by Iowa State University in 1893.

It was while occupying the professorial chair in Bowdoin College that Doctor White, in 1874, was asked by Lieutenant G. M. Wheeler, then in charge of the United States Geographieal and Geological Surveys West of the 100th Meridian, to prepare a report on the invertebrate fossils collected by the various expeditions of that organization. This was the beginning of a long service in the government bureaus. Two years later he was transferred to the Geological Surveys of the Territories, under Doctor H. V. Hayden, with whom, for a period of more than three years, he performed arduous duties in identifying and describing the old organic remains of the western country. With the merging of the four governmental surveys in 1879, Doctor White became Curator in Paleontology in the United States National Museum.

In 1882 Doetor White was appointed Geologist to the newly consolidated United States Geological Survey. Before entering fully upon his duties in this capacity he was detailed for a period of several months as chief of the Artesian Water Commission in the Great Plains Region, under the supervision of the Department of Agriculture. During the latter part of the same year he was commissioned by the Brazilian govern- 


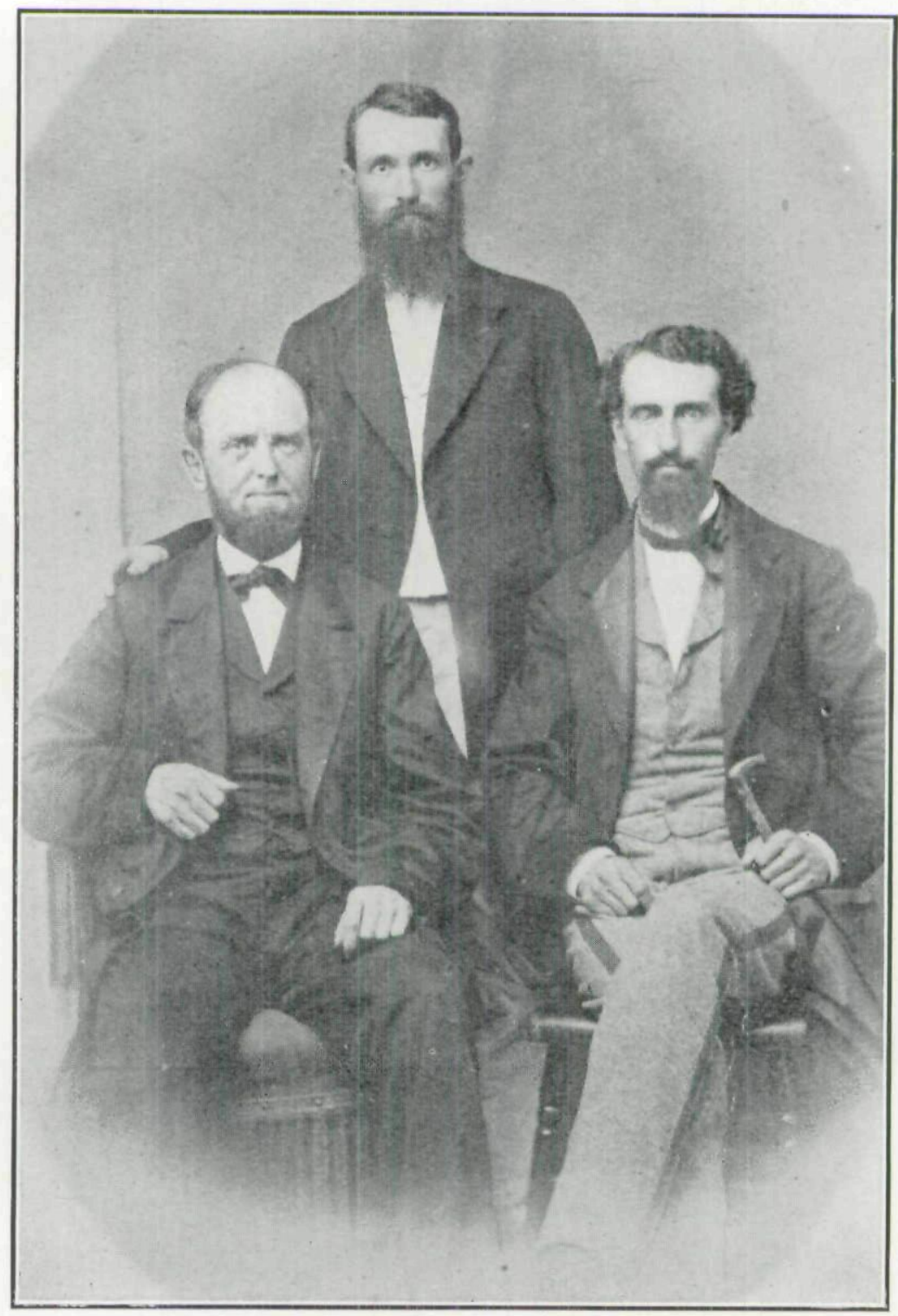

DR. C. A. WHITE State Geologist 
ment to make a report on the Cretaceous fossils which had been obtained in that country. He continued in the service of the Federal Survey until 1893, when he resigned to take up the duties of Scientific Associate in the Smithsonian Institute at Washington.

After fully entering upon his scientific eareer Doctor White traveled widely. His explorations in the various Government geological surveys took him, during a period of a score of years, into nearly every state and territory west of the Mississippi river. During two trips to Europe he visited many localities that were classic in geology. On one of these journeys he and his wife extended their itinerary into Egypt and Asia Minor.

In spite of his manifold duties Doctor White always took an active interest in the proceedings of the learned societies. In several of these he was chosen officer. He was president of the Biological Society of Washington two terms; VicePresident of the American Association for the Advancement of Science; and a member of the National Academy of Seiences. As one of the founders of the Geological Society of America he took a leading part in its debates. Besides membership in many seientific societies in this country he was corresponding member in the Geological Society of London, the Isis Gesellschaft für Naturkunde of Dresden, Saxony, the Royale Accademia Valdernese del Poggio, of Montevarchi, Italy, the Königlich-Kaiserlich Geologische Reichsanstalt of Vienna, Austria, and the Kaiserliche Leopoldiniseh-Carolinische Deutschen Akademie der Naturforscher, of Halle am Saale.

Doetor White was a voluminous writer. His pen was busy for a full half eentury. Between his first modest scientific paper of a dozen pages, published in Boston in 1862, and his last important memoir there was a large variety of subjects treated. The total number of titles is above 240. Of these no less than thirty-five relate to Iowa alone. His principal contributions to scientific literature deal with the invertebrate fossils. For many years the Cretaceous formations and their organic remains were his especial field of inquiry. During his 
long period of investigation he published the descriptions of hundreds of forms new to science. Indeed, this is the line of painstaking effort for which he will be longest remembered.

The subjects treated of in Doctor White's scientifie writings cover a wide field. They belong to the departments of zoology, botany, anthropology, paleontology, geology, history, medicine and domestic economy. Besides his more pretentious memoirs he wrote copiously for the general public in the newspapers and periodicals. With most happy results this method of presenting the most instructive and interesting facts to the people was adopted during the prosecution of the geological survey of Iowa.

Some idea of the comprehensiveness of Doctor White's investigations is gained by perusal of subjects discussed in his two most extensive accounts on Iowa geology. In the introduction to the first volume of the Iowa reports are included an historical statement, popular explanation, and a classification of Iowa rocks. Then in four long chapters are described the salient physical features and surface geology of the State. The general geological characters, and the relations of the rocks to one another are set forth in five chapters. The most striking aspects of seventeen counties are considered in the remainder of the volume. In the second volume the descriptions of the counties are continued, under four chapter headings. The second half of this volume treats of the economic geology, and is followed by three appendices.

On the whole Doctor White's scientific work was mainly pioneer effort. It was exploratory in nature and as such it was necessarily carried on in somewhat desultory fashion and under great difficulties. Many of his earlier published observations, on Iowa's mineral resources, are frequently quoted to this day, after the lapse of half a century.

Doctor White had a large personal aequaintance with men of science from all over the world. His correspondence with these and other men of large affairs was extensive. Many of these communications have so important an historical value that, shortly before his demise, he deposited a large number of them with the Historical Department of Iowa, together with 
all of his diplomas, testimonials, commissions, and other similar documents. He made this disposition of these papers because he grew up to a citizenship in this State, and always continued to regard himself as a eitizen of Iowa.

Doctor White was the last of that small but renowned group of American naturalists who, in the third quarter of the Nineteenth century, acquired international distinction. Iowa may well feel proud of counting him one of her most distinguished sons.

As has been already stated Doctor White was a wide and observant traveler. This extensive contact with both humanity and nature gave him a breadth and catholicity of sympathy such as is displayed in the character of but few men. When some years ago an eminent scholar aptly remarked that the circle of American scientific men who, at least in the earlier periods of their work, may be most eorrectly deseribed as naturalists grows smaller year by year, he must have had in mind Doctor White's own coterie of friends. Like many Americans who have attained prominence in fields of science Doctor White began with medicine.

Once, at a special session of the Geological Society of America held to do homage to the name and fame of one of the country's most distinguished sons, Doctor White, a short time before his own demise, when ealled upon to say something concerning his late friend, spoke feelingly words which with even greater appropriateness now apply to him. As now recalled these remarks were about as follows:

In addition to the features of the life and work of our departed colleague to which we already have called attention,- -his breadth and largeness of view, his hospitality to new truth, and his courage in advocating it,--we must not fail to name the personal qualities that have insured for him a lasting place in our affections and regard. In his candor, his fairness, his courtesy, he approached the ideal of the searcher for the truths of nature; in his devotion to his work he literally knew no limit, save that which the narrow house and the long sleep impose upon us all.

For nearly a quarter of a century it was a source of constant pleasure to feel assured that I was numbered among Doctor White's friends. Each meeting was a new and"lasting 
delight. His was a strong personality. His kindly sympathy grew stronger with the passing years. He not only possessed all the cardinal virtues of the ancients-justice, prudence, temperance, and fortitude,- - but he was ever generous and charitable. His love for his family and kindred amounted almost to a passion, and his kindness of heart extended to all with whom he came in contact. He was deliberate and careful in forming his opinions, and once formed he held them with firmness; but in upholding them he never descended to personalities, and no word was ever uttered by him that left a sting on the memory of his opponent, even when vanquished. $\mathrm{He}$ was wise and learned, a kind and true friend, an exemplary eitizen, and, best of all, an honest man.

\section{JOURNALISM.}

The late Rev. Dr. Peabody, in a letter to N. P. Willis, took occasion to rebut the notion that newspaper writing is necessarily of small aceount and influence. He said (we quote from the Home Journal) :

How many of the best works have been fragmentary and occasional? Not to mention half the literature of the timeessays, reviews, lectures, sermons, speeches-Bacon's Essays, Feltham, The Spectator, Rambler, and numberless other works have been as fragmentary as your articles; but their influence has been none the less on that account. **** A journalist, after all, has great advantages. He writes both in the presence of his subject and his audience.

I know of no way in which an author of ability is more sure of a speedy return-in the shape of influence and usefulness-for the most conscientious and eareful labors, than by addressing the public through the newspaper press.

Signourney-Life in the West, March 19, 1857. 
Copyright of Annals of Iowa is the property of State of Iowa, by \& through the State Historical Society of Iowa and its content may not be copied or emailed to multiple sites or posted to a listserv without the copyright holder's express written permission. However, users may print, download, or email articles for individual use. 